\title{
Trenger vi epidemiologi?
}

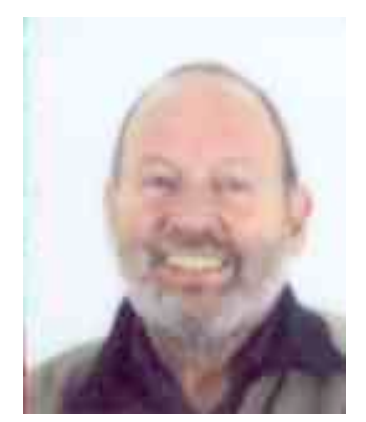

Professor Dag Thelle,

Leder i Norsk forening for epidemiologi

I et foredrag for noen år tilbake, sa Kenneth Rothman at han i 2004 trolig ville holde et innlegg som konkluderte med at epidemiologien hadde vært en forbigående disiplin som blomstret i siste halvdel av forrige århundre. Den ga oss en del analytiske metoder, lærte oss om en rekke trivielle risikofaktorer og døde deretter ut. Arenaen ble overlatt til andre helsefag.

Fra sosiologisk hold har det kommet en annen type kritiske bemerkninger, som for eksempel Alan Petersen og Deborah Luptons bok "The new public health" fra 1996. De mener at vår tids fokusering på helse (et individuelt gode som vi selv har ansvaret for) og miljø (der vi har ansvaret for hele klodens fremtid) pålegger oss overmenneskelige oppgaver og leder til moralisering, utstøting, og diskriminering. De legger mye av skylden på epidemiologien. Alt underkastes undersøkelser med risiko for uhelse som endepunkt for prosjektene. Epidemiologene spiller en hovedrolle for å finne fram sannheten om sykdommene, risikofaktorene og identifisere risikoindividene. Vårt nære forhold til etablissementet har beskyttet oss mot kritisk granskning, og våre vitenskapelige metoder har gitt oss skinn av objektivitet og rasjonalitet. Petersen og Lupton konkluderer med at nettopp epidemiologien i en neoliberalistisk tid har bidratt til segregasjon, diskriminering og fordømming, omtrent som på slutten av forrige århundre.

Samtidig forteller andre samfunnsvitere oss at vi i for liten grad tar tak i de egentlige årsakene til dårlig helse; den ulike fordelingen av ressursene både på lokalt og globalt nivå, og betydningen av dette for folkehelsa. Vi blir med andre ord anklaget for at utviklingen går mot større segregasjon, for ikke å påvirke det politiske grunnlaget for økende ulikheter, og for å være opptatt av trivielle risikofaktorer.

I hvilken grad vi bidrar til økende ulikheter skal jeg la ligge, men anklagen om at den kunnskapen som blir frembragt ikke kommer til anvendelse og at risikofaktorene er trivielle, bør vi se nærmere på.

Norsk epidemiologi er preget av store standardiserte datainnsamlinger. Vi har opplysninger på individnivå som gir muligheter til trendanalyser som snart dekker tretti år. Dette er data som ofte er publisert i interne rapporter som tilflyter allmennheten mer eller mindre tilfeldig. I liten grad er dataene blitt etterspurt av sentrale helsemyndigheter, selv om enkelte rosiner er plukket ut, og publisert på internasjonalt nivå. Mye er uanalysert. Det gjelder for eksempel utviklingen av fysisk aktivitet i befolkningen, endringer i kjente kardiovaskulære risikofaktorer, selvopplevd helse og sosiale variabler. Dette blir vi gjerne konfrontert med når vi søker om midler til nye befolkningsundersøkelser: analyser først det dere har, deretter kan dere eventuelt komme tilbake med nye søknader. Noe av årsaken til denne situasjonen er trolig at vi i for liten grad presiserer at epidemiologisk forskning i første rekke er årsaksrettet forskning. Vi er opptatt av etiologiske sammenhenger. De standardiserte befolkningsundersøkelsene har hatt flere hensikter, hvor overvåking av enkelte helseparametre kanskje har vært den viktigste ved siden av av identifisering av høyrisikoindivider. Det forutsetter at metoder for datainnsamling er standardisert og ikke endres vesentlig over tid. Dermed blir det begrensete mulighetet til å undersøke nye hypoteser.

Jeg tror ikke Rothman får rett, men ansvaret for å vise at epidemiologisk forskning kan bidra til vesentlig kunnskap om årsaker til sykdom ligger på oss selv. Vi må forbedre våre metoder, følge med utviklingen i molekylær biologi og kunne planlegge miljø-genetiske epidemiologiske studier som forklarer hvorfor sykdommer varierer som de gjør. Det forutsetter et langt nærmere samarbeid med basalfagsforskere og klinikere enn det som har vært tilfelle for mange oss tidligere.

\footnotetext{
Dag Thelle

Medicin, Centralkliniken Sahlgrenska Universitetssjukhuset/Östra S-413 65 Göteborg, Sverige

telefon: 0046313434067 telefax: 004631258933 e-post: dag.thelle@hjl.gu.se
} 